JURNAL SEHAT MASADA VOLUME XIV NOMOR 1 Januari 2020 ISSN : 1979-2344

\title{
HUBUNGAN POLA ASUH ORANG TUA DENGAN PERILAKU PICKY EATER PADA ANAK USIA PRASEKOLAH
}

\author{
Depi Lukitasari \\ Program Studi Sarjana Keperawatan STIKes Dharma Husada Bandung \\ depilukita@yahoo.com
}

\begin{abstract}
ABSTRAK
Pilih-pilih makanan (picky eater) adalah perilaku anak tidak mau atau menolak untuk makan, atau mengalami kesulitan mengkonsumsi makanan. Picky eater dipengaruhi oleh pola asuh, perilaku makan orang tua, interaksi ibu dan anak, pemberian ASI eksklusif, MPASI, dan psikologis serta kondisi fisik anak. Tujuan penelitian untuk mengetahui hubungan pola asuh orang tua terhadap terjadinya picky eater pada anak usia prasekolah. Desain penelitian observational analytic jenis cross sectional. Populasi ibu yang memiliki anak prasekolah sebanyak 74 orang, teknik sampling yg digunakan adalah total sampling. Pengambilan data dilaksanakan pada Desember 2018 - Januari 2019, instrumen penelitian menggunakan kuesioner PSQ dan CEBQ. Hasil penelitian bahwa rata-rata responden berpola asuh demokratis sebanyak 30 responden $(65.2 \%)$ dengan anak non picky eater. Hasil hitungan didapatkan Analisis data menggunakan uji chi square, $\alpha=0,041$ artinya Ho ditolak terdapat hubungan pola asuh orang tua terhadap terjadinya picky eater pada anak usia prasekolah. Simpulan pola asuh demokratis yang diterapkan mampu menjadikan anak tidak picky eater.
\end{abstract}

Kata Kunci : picky eater, pra sekolah

\section{PENDAHULUAN}

Kesulitan makan (picky eater) adalah perilaku anak tidak mau atau menolak untuk makan, atau mengalami kesulitan mengkonsumsi makanan atau minuman dengan jenis dan jumlah sesuai usia secara fisiologis (alamiah dan wajar), yaitu mulai dari membuka mulutnya tanpa paksaan, mengunyah, menelan, hingga sampai terserap di pencernaan secara baik tanpa paksaan dan tanpa pemberian vitamin dan obat tertentu. (Judarwanto, 2006 dalam Priyanah, 2008).

Proses perubahan pola makan biasanya sering terjadi pada anak usia prasekolah dimana anak pada umumnya mengalami kesulitan untuk makan. Pada masa ini anak sudah menunjukkan proses kemandirian dimana perkembangan kognitif sudah mulai menunjukkan perkembangan, dan anak sudah mempersiapkan diri untuk memasuki sekolah, anak juga membutuhkan pengalaman belajar dari lingkungan dan orang tuanya, proses pembelajaran makan yang baik sangat penting bagi anak di fase usia prasekolah agar ia tumbuh sehat dan cerdas (Hidayat, 2012).

Studi populasi di London, Inggris, anak berumur 3 tahun 17\% digambarkan memiliki nafsu makan yang buruk dan sebanyak $12 \%$ diantaranya mengalami picky eater (Shore, Piazza, 1997 dalam Priyanti, 2013). Prevalensi picky eater di Indonesia terjadi pada anak sekitar 20\%, dan dari anak picky eater $44,5 \%$ 
mengalami malnutrisi ringan sampai sedang, dan $79,2 \%$ dari subjek penelitian telah mengalami picky eater lebih dari 3 bulan (Dewanti, 2012; Lubis, 2005 dalam Priyanti, 2013)

Memilih-milih makanan (picky eater) merupakan masalah pada anak yang perlu diperhatikan baik oleh orang tua maupun praktisi kesehatan, karena picky eater pada anak memiliki efek yang merugikan, baik bagi pengasuh ataupun anak itu sendiri. Picky eater banyak terjadi pada umur 1 sampai 3 tahun dan berisiko dua kali lebih besar untuk mempunyai berat badan rendah pada umur 4,5 tahun. Anak dengan perilaku picky eater hanya mengonsumsi jenis makanan tertentu, menghindari jenis makanan baru, dan memiliki preferensi pangan yang kuat (Jacobi et al. 2008).

Menurut Soetjiningsih (2008), kelainan perilaku sulit makan disebabkan beberapa faktor, antara lain kebiasaan makan, psikologis, dan organik. Kelainan kebiasaan makan biasanya disebabkan oleh faktor lingkungan seperti mengikuti kebiasaan makan teman sebaya atau orang-orang sekitar, menyukai dan menolak jenis makanan yang sama pada waktu yang berbeda, atau suka memakan makanan yang tidak sesuai dengan usianya. Faktor psikologis sebenarnya masih ada hubungannya dengan pola asuh karena psikologis anak sangat ditentukan dari cara pengasuhan, lingkungan dan juga hubungan didalam keluarga, semakin baik hubungan dalam keluarga maka semakin kecil kemungkinan untuk anak mengalami anoreksia psikogenik atau kesulitan makan karena gangguan psikologis.

Sikap orang tua dan hubungannya dengan anak, atau biasa disebut pola asuh, menentukan terjadinya gangguan psikologis yang dapat mengakibatkan gangguan perilaku makan. Orang tua banyak mempengaruhi perkembangan pola makan pada anak. Studi kuantitatif yang dipublikasikan tahun 1998 menguji pemilihan makan pada batita yang berhubungan dengan pemilihan makan anggota keluarganya (Skinner et al,1998 dalam Priyanah, 2008). Penelitian lain juga menunjukkan bahwa praktek pemberian makan yang salah dari orang tua atau karena kurang pengalaman dapat menyebabkan anak gagal tumbuh (Wiliams,2005 dalam Priyanah, 2008).

Penanganan yang salah terhadap perilaku picky eater oleh orang tua merupakan salah satu penyumbang peningkatan status gizi kurang maupun gizi buruk pada anak Indonesia (Kurniasih, 2010 dalam Priyanti, 2013). Picky eater terjadi karena beberapa faktor penyebab salah satu faktor penyebab yaitu pola asuh orang tua (Savage dkk., 2007).

Pola asuh orangtua diidentifikasi melalui adanya perhatian dan kehanggatan, yaitu orang tua dalam mengasuh dan menjalin hubungan interpersonal dengan anak disadari adanya perhatian, penghargaan dan kasih sayang, kebebasan berinisiatif, yaitu kesediaan orangtua untuk memberikan kesempatan kepada anak untuk menyampaikan dan mengembangkan pendapat ide, pemikiran 
dengan tetap mempertimbangkan hak-hak orang lain, nilai dan norma yang berlaku Tipe pola asuh dibagi menjadi 3, yaitu tipe demokratis, otoriter dan permisif. Ketiga jenis pola asuh ini dapat memengaruhi sikap dan tindakan dalam makan (Kridiyanto,2013).

Perilaku orangtua sangat penting dalam tumbuh kembang anak dalam psikologis anak, kemampuan bersosialisasi anak, kemandirian anak,serta perilaku sulit makan pada anak. Beberapa factor yang dapat mempengaruhi pemberian makan pada anak antara lain interaksi anak dan orangtua (pola asuh), keperibadian anak, lingkungan dan budaya. Penelitian yang telah dilakukan judarwanto (2006) menyebutkan bahwa anak usia 4-6 tahun, mendapatkan prevalensi kesulitan makan terbesar 33,6 \% sebagian besar $(79,2 \%)$ telah berlangsung lebih dari 3 bulan, data ini dipengaruhi oleh gaya dari pola asuh orangtua (Markum,A.H, 2010).

Berdasarkan hasil penelitian yang dilakukan Najib (2016) didapatkan bahwa pola asuh yang baik adalah pola asuh demokratis, karena cenderung mendorong anak bebas tetapi tetap memberikan batasan dan mengendalikan tindakan-tindakan mereka, pola asuh ini tidak mementingkan kepentingan orang tua diatas kepentingan anak begitu juga sebaliknya sehingga mampu mengarahkan kegiatan anak secara rasional, menghargai anak serta mendorong keputusan anak untuk mandiri. Hal tersebut membuktikan bahwa pola asuh demokratis dapat mempengaruhi perilaku makan anak usia prasekolah sehingga anak mempunyai perilaku makan yang baik dalam arti tidak sulit pada saat diberikan makan. Anak yang diasuh dengan pola asuh permisif perkembangan kepribadiannya akan tidak terarah karena orang tua tidak mengendalikan perilaku sesuai dengan kebutuhan perkembangan kepribadian anak. Orang tua atau pengasuhan yang tidak pernah menegur atau tidak berani menegur perilaku anak meskipun perilaku anak tersebut sudah keterlaluan atau diluar batas kewajaran. Berdasarkan teori tersebut pola asuh permisif cenderung menyebabkan anak sulit makan.

Penelitian lainnya membuktikan bahwa sebagian besar orang tua yang menggunakan pola asuh permisif dan otoriter memiliki anak yang sulit makan, proporsi dari masing-masing berturut-turut adalah $57,5 \%$ dan $66,7 \%$. Sedangkan orang tua yang menggunakan pola asuh demokratis cenderung memiliki anak yang tidak sulit makan $(53,8 \%)$. Penelitian lainnya yang dilakukan Harbran (2013) memperkuat pernyataan bahwa beberapa anak yang diasuh dengan demokratif tidak mengalami picky eating, sedangkan beberapa anak mengalami picky eating diasuh dengan permisif.

Kebiasaan makan anak dipengaruhi oleh hubungan antara orang tua atau pengasuh dengan anak melalui pola asuh dalam pemberian makan. Memilih-milih makanan (picky eater) merupakan masalah pada anak yang perlu diperhatikan baik oleh orang tua maupun praktisi kesehatan, karena picky eater pada anak memiliki efek yang merugikan 
terutama bagi anak karena nutrisi perilaku sulit makan dapat mengurangi asupan nutrisi pada anak prasekolah yang salah satu faktor penyebanya adalah pola asuh orang tua yang salah.

Hasil wawancara yang sudah dilakukan peneliti di PAUD Mawar Sari kepada 12 orang ibu mengeluh bahwa anaknya mengalami sulit makan 7 diantaranya mengatakan anaknya hanya ingin makan yang disukai saja, dan 6 orang ibu mengatakan anaknya suka meminta jajan dan terkadang tidak mau di bawakan bekal dari rumah sehingga beberapa ibu seringkali harus membujuk anak agar anak mau makan baik dengan paksaan maupun ancaman dan sebagian lagi mengatakan ada yang menuruti permintaan anak, ada yang menerapkan dispilin yang berlebihan, dan ada yang menjunjung tinggi kemandirian anak.

Berdasarkan fenomena tersebut maka penulis tertarik untuk meneliti hubungan pola asuh dengan perilaku picky eater pada anak usia prasekolah.

\section{METODE PENELITIAN}

Jenis penelitian yang digunakan dalam ini adalah penelitian kuantitatif. Dengan menggunakan metode pendekatan cross sectional yaitu suatu penelitian yang dilakukan untuk mengetahui hubungan antara pola asuh dengan perilaku picky eater pada anak prasekolah. Populasi dalam penelitian ini adalah seluruh orang tua yang memiliki anak usia 3-5 tahun di wilayah Sukanegla RW 01 sebanyak 74 Orang. Teknik pengambilan sampel dalam penelitian ini adalah total sampling. Instrumen penelitian menggunakan kuesioner PSQ dan CEBQ. Pengambilan data dilaksanakan pada Desember 2018 - Januari 2019

\section{HASIL PENELITIAN}

Tabel 1 Distribusi Frekuensi Berdasarkan Penerapan Pola Asuh Orang Tua $(n=74)$

\begin{tabular}{lcc}
\hline \multicolumn{1}{c}{ Pola asuh } & F & \% \\
\hline Otoriter & 19 & 25,7 \\
Demokrasi & 46 & 62,2 \\
Permisif & 9 & 12,1 \\
\hline
\end{tabular}

Berdasarkan tabel 1, penerapan pola asuh orang tua anak usia prasekolah paling banyak 46 orang $(62,2 \%)$ yaitu pola asuh demokrasi.

Tabel 2 Distribusi Frekuensi berdasarkan perilaku picky eater pada anak usia prase

\begin{tabular}{lcc}
\hline \multicolumn{1}{c}{ Pola asuh } & F & \% \\
\hline Picky eater & 35 & 47,3 \\
Non picky eater & 39 & 52,7 \\
\hline
\end{tabular}

Berdasarkan tabel 2, dari 74 anak prasekolah $47,3 \%$ anak mengalami picky eater.

\section{Tabel 3 Hubungan Pola Asuh Orang Tua Dengan Perilaku Picky Eater Pada Anak Usia Prasekolah $(n=74)$}

\begin{tabular}{lcccccccc}
\hline \multirow{2}{*}{$\begin{array}{c}\text { Pola Asuh } \\
\text { Orang Tua } \\
\text { (Ibu) }\end{array}$} & \multicolumn{9}{c}{$\begin{array}{c}\text { Picky } \\
\text { eater }\end{array}$} & $\begin{array}{c}\text { Non picky } \\
\text { eater }\end{array}$ & \multirow{2}{*}{ Total } & \multirow{2}{*}{ P } \\
\cline { 2 - 6 } & F & $\%$ & F & $\%$ & F & $\%$ & \\
\hline Otoriter & 14 & 73,7 & 5 & 26,3 & 19 & 100 & \\
Demokrasi & 16 & 34,8 & 30 & 65,2 & 46 & 100 & 0,041 \\
Permisif & 5 & 55,0 & 4 & 44,4 & 9 & 100 & \\
\hline Jumlah & 35 & 47,3 & 39 & 52,7 & 74 & 100 & \\
\hline & & & & & & &
\end{tabular}


Berdasarkan tabel 3, didapatkan hasil uji Chi Square menunjukan bahwa p-value $\alpha<0,05$ yang berarti terdapat hubungan yang signifikan antara pola asuh orang tua dengan kejadian picky eater $(\mathrm{p}$-value $=0,041)$.

\section{PEMBAHASAN}

Dari hasil Uji Chi Square tentang Hubungan Pola Asuh Orang Tua Dengan Perilaku Picky Eater Pada Anak Usia Prasekolah didapatkan nilai $P$ value $0,041<a$ 0,005 . Hal tersebut menunjukkan bahwa ada Hubungan Pola Asuh Orang Tua Dengan Perilaku Picky Eater Pada Anak Usia Prasekolah.

Kebiasaan makan anak dipengaruhi oleh hubungan antara orang tua atau pengasuh dengan anak melalui pola asuh dalam pemberian makan. Menurut Suhendi, (2010) pola asuh terbagi atas : "1) pola asuh otoriter yaitu pola asuh yang menerapkan pengawasan yang ketat dan hukuman. 2) pola autoritatif yaitu pola asuh yang menerapkan kehangatan dan komunikasi yang baik dengan anak. 3) pola asuh permisif yaitu pola asuh yang tidak memperdulikan pengembangan kreatifitas anak." (Suhendi, 2010).

Orang tua menggunakan tekanan dan restriksi (pola asuh otoriter) dalam praktik pemberian makan yang non-responsif dapat menyebabkan anak memiliki perilaku picky eating. Pola asuh pengabaian dan permisif juga menggunakan praktik makan non responsif. Sebaliknya, anak yang diasuh secara demokratif cenderung memiliki kebiasaan positif yaitu menerima makanan dan belajar mengenai respon terkait isyarat lapar dan kenyang sehingga anak mengembangkan kebiasaan makan sehat. Pola asuh demokratif menggunakan praktik makan responsif (responsive feeding).

Hasil penelitian menunjukan paling banyak pola asuh orang tua anak usia prasekolah 46 orang $(62,2 \%)$ memiliki pola asuh demokrasi. Dimana pada pola asuh ini orang tua lebih memperhatikan kebebasan dan menghargai anak yang sesuai dengan keinginannya. Pada penelitian ini sebagian besar anak yang mengalami picky eater diasuh dengan pola asuh otoriter dan permisif.

Pola asuh orang tua merupakan interaksi antara orang tua dan anak dalam berkomikasi, mendidik, mengasuh, dan terus berkelanjutan dari waktu kewaktu. Dengan pola asuh yang diterapkan orang tua anak dapat berinteraksi dengan lingkungan mengenai dunia sekitar serta mengenal pergaulan hidup yang berlaku dilingkungannya.

Menurut Baumrind gaya pola asuh orang tua demokrasi yang digunakan untuk mengasuh anak berdasarkan tingkat pengasuhan (Nurtering), tuntutan (Maturity demands), komunikasi dan kontrol terhadap prilaku anak. Sikap pola asuh menunjukkan perbedaan alamiah yang muncul dari nilai-nilai yang diajarkan, perlakuan orang tua, perilaku responsif dan tuntutan (Ribeiro, 2009).

Pola asuh demokratis merupakan suatu bentuk pola asuh yang memperhatikan dan 
JURNAL SEHAT MASADA VOLUME XIV NOMOR 1 Januari 2020 ISSN : 1979-2344

menghargai kebebasan anak, namun kebebasan itu tidak mutlak, orang tua memberikan bimbingan yang penuh pengertian kepada anak. Pola asuh ini memberikan kebebasan kepada anak untuk mengemukakan pendapat, melakukan apa yang diinginkannya dengan tidak melewati batas-batas atau aturan-aturan yang telah ditetapkan orang tua. Dalam pola asuh ini ditandai sikap terbuka antara orang tua dengan anak. Mereka membuat aturan-aturan yang telah disetujui bersama. Anak diberi kebebasan untuk mengemukakan pendapat, perasaan dan keinginannya. Jadi dalam pola asuh ini terdapat komunikasi yang baik antara orang tua dengan anak. Sehingga dengan pola asuh demokratis anak akan menjadi orang yang mau menerima kritik dari orang lain, mampu menghargai orang lain, mempunyai kepercayaan diri yang tinggi dan mampu bertanggung jawab terhadap kehidupan sosialnya (Gunarsa, 2012).

Pola asuh otoriter adalah sentral artinya segala ucapan, perkataan, maupun kehendak orang tua dijadikan patokan (aturan) yang harus ditaati oleh anak-anaknya. Supaya taat, orang tua tidak segan-segan menerapkan hukuman yang keras kepada anak. Pola asuh otoriter merupakan cara mendidik anak yang dilakukan orang tua dengan menentukan sendiri aturan-aturan dan batasan-batasan yang mutlak harus ditaati oleh anak tanpa kompromi dan memperhitungkan keadaan anak. Orang tualah yang berkuasa menentukan segala sesuatu untuk anak dan anak hanyalah objek pelaksana saja. Jika anak membantah, orang tua tidak segan-segan akan memberikan hukuman, biasanya hukumannya berupa hukuman fisik (Gunarsa, 2012). Akan tetapi apabila anak patuh maka orang tua tidak akan memberikan pengahargaan karena orang tua mengganggap bahwa semua itu adalah kewajiban yang harus dituruti oleh seorang anak. Jadi, dalam hal ini kebebasan anak sangat dibatasi oleh orang tua, apa saja yang akan dilakukan oleh anak harus sesuai dengan keinginan orang tua. Jika anak membantah perintah orang tua maka akan dihukum, bahkan mendapat hukuman yang bersifat fisik dan jika patuh orang tua tidak akan memberikan hadiah (Gunarsa, 2012).

Pola pengasuhan otoriter kebanyakan diterapkan oleh orangtua yang berasal dari pola pengasuhan otoriter pula di masa kanakkanaknya, atau oleh orangtua yang sebenarnya menolak kehadiran anak. Orang tua yang menerapkan pola asuh otoriter cenderung tidak memikirkan apa yang akan terjadi di masa akan datang fokusnya lebih kepada masa kini. Orangtua menilai dan menuntut anak untuk mematuhi standar mutlak yang ditentukan sepihak oleh orangtua, memutlakkan kepatuhan dan rasa hormat atau sopan santun. Orangtua merasa tidak pernah berbuat salah (Suhendi, 2010).

Pada pola asuh permisif Meskipun anakanak dengan pola pengasuhan ini cenderung lebih energik dan responsive diandingkan anak-anak dengan pola pengasuhan otoriter, namun mereka tampak kurang matang secara sosial (manja), impulsive, memetingkan diri 
sendiri, dan kurang percaya diri. Banyak orangtua yang terlalu sibuk dengan kegiatannya sendiri dengan berbagai macam alasan pembenaran.

Pola asuh orang tua permisif bersikap terlalu lunak, tidak berdaya, memberi kebebasan terhadap anak tanpa adanya normanorma yang harus diikuti oleh mereka. Mungkin karena orang tua sangat sayang (over affection) terhadap anak atau orang tua kurang dalam pengetahuannya. Akibatnya anak berperilaku sesuai dengan keinginannya sendiri, tidak peduli apakah hal itu sesuai dengan norma masyarakat atau tidak. Keadaan lain pada pola asuh ini adalah anak-anak bebas bertindak dan berbuat (Gunarsa, 2012). Pada pola asuh permisif, masing-masing mempunyai kelebihan dan kekurangan. Prinsip dasar demokratis, yaitu tingginya kontrol dan kehangatan. Pada tingginya kontrol akan melengkapi pada kekurangan pola asuh permisif yang akibatnya anak kurang mampu untuk mengntrol diri.

Pola asuh demokratis menunjukan pengasuhan lebih banyak menggunakan Responsive feeding yaitu hubungan timbal balik antara anak dan pengasuh dengan komunikasi secara verbal dan non-verbal terkait perasaan lapar dan kenyang yang diikuti respon dari pengasuh. Lima prinsip utama responsive feeding, yaitu menyuapi langsung atau membantu anak makan sendiri, memberi makan perlahan, sabar dan mendorong anak untuk makan, respon terhadap penolakan makan, memberi makan di lingkungan yang aman, dan waktu makan adalah waktu untuk belajar dan mengasihi. Responsive feeding dapat dilakukan untuk menanggulangi kejadian picky eating karena responsive feeding dapat meningkatkan kemampuan self-feeding anak dan respons terhadap bahasa verbal ibu, melatih anak untuk mengonsumsi makanan keluarga dan makan sendiri (self feeding). Selain itu, melatih anak untuk berperilaku makan yang baik, disiplin, dan dapat menghargai makanan dan waktu makan.

Menurut Gunarsa (2012) pola asuh orang tua terhadap anak merupakan bentuk interaksi antara anak dan orang tua selama mengadakan kegiatan pengasuhan yang berarti orang tua mendidik, membimbing, dan mendisiplinkan serta melindungi anak untuk mencapai kedewasaan sesuai dengan norma-norma yang berlaku dalam lingkungan setempat dan masyarakat.

Kebiasaan makan anak dipengaruhi oleh hubungan antara orang tua atau pengasuh dengan anak melalui pola asuh dalam pemberian makan. Orang tua menggunakan tekanan dan restriksi (pola asuh otoriter) dalam praktik pemberian makan yang non-responsif dapat menyebabkan anak memiliki perilaku picky eating. Pola asuh pengabaian dan permisif juga menggunakan praktik makan non responsif. Sebaliknya, anak yang diasuh secara demokratif cenderung memiliki kebiasaan positif yaitu menerima. 
JURNAL SEHAT MASADA VOLUME XIV NOMOR 1 Januari 2020 ISSN : 1979-2344

\section{SARAN}

Hasil penelitian diharapkan sebagai salah satu evidence based dalam mendidik orang tua mengenai penerapan pola asuh yang tepat yang mampu merubah kebiasaan makan pada anak.

\section{DAFAR PUSTAKA}

Adriani, M. dan Kartika, V., 2011. Pola Asuh Makan pada Balita dengan Status Gizi Kurang di Jawa Timur, Jawa Tengah dan kalimantanTengah, Tahun 2011. Buletin Penelitian Sistem kesehatan, Vol 16 (2): 185193.

Anggraini, I. R. (2014). Perilaku Makan Orang Tua dengan Kejadian Picky Eater Pada Anak Usia Toddler. Jurnal Keperawatan, 154-162.

Chao, H. dan Chang,2016. pickky Eating Behaviors Linked toInappropriate CaregiverChild Interaction, Caregiver Intervention, and Impaired General Development in Children. Pediatrics and Neonatology

Hariani, R.E., Amareta, D.I., \& Suryana, A.L., 2016. Pola Pemberian ASI dan Makanan Pendamping ASI Terhadap Grafik Pertumbuhan pada Kartu Menuju
Sehat (KMS). Jurnal Ilmiah INOVASI, Vol. 1(1):41-46.

Hockenberry, M., Wilson, D., Rodgers, C., 2016. Wong's Essentials of Pediatric Nursing $\left(10^{\text {th }} e d\right)$. Canada: Elsevier Health Sciences.

Lam, J., 2015. Picky Eating in Children. Frontiers in Pediatrics, 3:41

Lestari, P. 2013. Hubungan Pola Asuh Ibu Tentang makanan dengan Status Gizi Anak Prasekolah di kelurahan Semanggi dan Sangkrah kecamatan Pasar Kliwon Surakarta. Naskah Publikasi, Universitas Muhammadiyah Surakarta

Mascola, A. J., Bryson, S. W., \& Agras, W. S. (2010). Picky eating during childhood: a longitudinal study to age 11 years. Eating Behaviors, 11(4), 253-257

Mirayanti, N.A., 2012. Hubungan Pola Asuh Pemenuhan Nutrisi dalam keluarga dengan Status Gizi Balita di Kelurahan Pasir Gunung Selatan kecamatan Cimanggis Kota Depok. Tesis, Universitas Indonesia. 